\title{
Visas: Not Everywhere You Want to Be or The American Non-Express
}

This letter is not about credit cards, despite the title. It is about the U.S. visa system, the U.S. government's view of both non-U.S. citizens and scientists, and what this has meant for our nonU.S. colleagues.

Secured by an ocean on each side, the United States has never felt seriously threatened by an outside power. The intentional demolition of the World Trade Center Towers and portions of the Pentagon on 9/11 was unimaginable to most Americans. I myself had been in China on 9/11, giving lectures at the Harbin Institute of Technology. One of my student guides broke the news to me with many apologies, explaining that both the World Trade Center and the "Five Corners Building" (it took me a while to get that one) had been hit. I was surprised and intensely curious, but being cut off from the U.S. media meant I had no sense of the reaction back home. When I returned, I found a nation of stunned people. The public feeling was much like finding out your child-your child, your healthy, happy child-had cancer. People were literally sick with distress for months. I can remember whole business lunches where no one wanted to talk above a whisper.

Given the emotional impact of $9 / 11$, the passage of the Patriot Act was a forgone conclusion. This Act gave up many traditional freedoms for the prospect of a safer America. This is when the visa delays started-mandatory FBI background checks for each applicant, mandatory tracking of all students (and, in some cases, their families) by university staff (implemented February 2003), mandatory in-person interviews for each visa applicant (May 2003), mandatory fingerprinting (coming January 2004), and mandatory machine readable passports (by October 2004; October 2003 for some countries). It is not clear what hurdle will come next, but the "visa challenge" has probably been the first nonmonetary political issue to affect the materials science community. This is what we have learned.

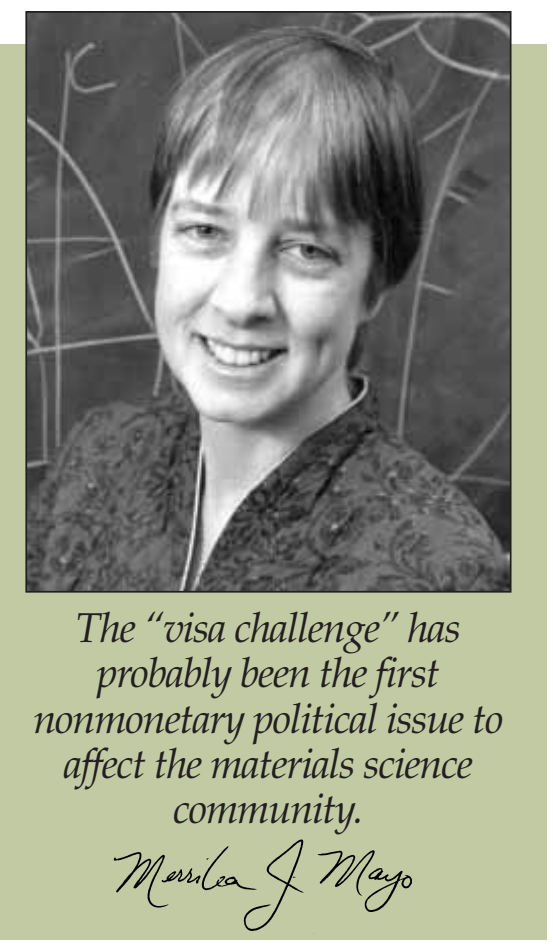

Materials science is a very, very dangerous profession.

It is hard to think of myself as a danger to anyone. But, post-9/11, technical knowledge is considered a dangerous thing by many U.S. citizens. The Technical Alert List, which is used by consular offices to screen visa applicants, includes the following "critical fields of study" that consular officers should watch for:

- Advanced metals and alloys

- Noncomposite ceramic materials

- Ceramic, cermet, organic, and carbon materials

- Polymeric materials

- Synthetic fluids

- Hot isostatic pressing

- Densification

- Intermetallic compounds/alloys

- Organometals

- Liquid and solid lubricants

- Magnetic metals

\section{To Register Visa Concerns}

Researchers or students who are experiencing problems obtaining a visa may register their case online with the U.S. National Academies through the questionnaire at Web site http:/ / www7.nationalacademies.org/visas/index.html. This registration will assist the National Academies in tracking the case.

In addition, researchers/students or their hosts may send a letter of complaint to Dr. Charles McQueary, Under Secretary for Science and Technology, Department of Homeland Security, 7th and D Sts. NW, Washington, DC 20001 USA.

- Chemical absorption

- Quantum wells, resonant tunneling

- Superconductivity

- Advanced optoelectronics

- Aerospace thermal (such as superalloys) and high-performance structures

- Spray or drum-drying technology

- Milling equipment or technology intended for the production of micron-sized particles.

According to this list, I am either a national treasure or a national threat because I know at least a little bit about each of these areas. Probably any member of the Materials Research Society could claim the same.

Chinese students are more dangerous than anyone else.

The origin of this assumption is unknown, but it must be embedded deeply within the government because more U.S. visas are denied to Chinese students than to students of any other nation. The International Visitor's Office Web site at the U.S. National Academies has started to keep statistics on who is having problems getting visas - and the vast majority of cases reported by visitors to that site $(245 / 365)$ have been for Chinese applicants (this fact has also been borne out by other surveys). Why China was picked for the brunt of the post-9/11 terrorism crackdown is unclear. China is not on the list of countries known to harbor terrorists. In fact, the U.S. government's usual complaint is that fringe political groups cannot operate freely in China, so terrorism cannot be the issue here. China is a nuclear power, but citizens of the other known nuclear powers (e.g., India) do not appear to be having the same visa problems. One rumor is that the U.S. embassy in Beijing is simply much stricter in issuing visas than most of the other embassies. This almost makes some sense. Even the consulate in Shanghai is rumored to be a better place to obtain a visa than Beijing. To determine the protocols that the Beijing embassy is following, the president of the U.S. National Academy of Sciences plans to visit the Beijing embassy by the end of the year.

The scientific method of attacking a political problem is to collect data.

If one looks over the past two years of activity on the visa issue, there has been a large outcry by the scientific community in the United States with respect to how our overseas colleagues have been treated. 
However, the action plan has been almost universally to collect data: The American Institute of Physics (AIP), the Federation of Materials Societies (FMS) on request from MRS, and the Association of American Universities (AAU) all conducted surveys of their constituencies to see how bad the problem was. They found that aside from large numbers of denials to Chinese applicants, the problem was very frustrating (long delays, usually 3-6 months) but not too bad (few total rejections). At that point, active engagement stopped. A few ideas were floated-a special visa for scientists, preapproval for reentry in the case of students who go back home for visits to their families-but little was done. Even the prospective visit by the president of the U.S. National Academy of Sciences is being billed as a data-gathering mission.
At this point, it appears the visa problem is, for all practical purposes, a closed case. The universities in the United States will never have the access to students from China they once had, and the U.S. scientific community will never regain the trust we once had with the rest of the world. Sic transit gloria Americani.

MERRILEA J. MAYO 2003 MRS President

\section{Materials Research Society and the Optical Society of America Invite Applications for Their 2004-2005 Therifing Congressional Science and Engineering Fellowship}

\section{Program:}

- The Fellow spends one year working as a special legislative assistant on the staff of a member of Congress or congressional committee. Activities may involve conducting legislative or oversight work, assisting in congressional hearings and debates, and preparing briefs and writing speeches. The Fellow also attends an orientation program on congressional and executive branch operations, which includes guidance in the congressional placement process, and year-long seminar series on science and public policy issues. These aspects of the program are administered by the American Association for the Advancement of Science for the OSA/MRS Fellow, and those Fellows sponsored by nearly two dozen other scientific societies.

\section{Purpose:}

- To provide OSA and MRS members with an invaluable public policy learning experience, to contribute to the more effective use of optical and materials science knowledge in government, and to broaden awareness about the value of scientist and engineer-government interaction among OSA and MRS members and within the federal government.

\section{Criteria:}

- A prospective Fellow must demonstrate a record of success in research or scholarship, in a field relevant to materials and/ or optical science and technology. The Fellow must also demonstrate sensitivity toward policy issues and have a strong interest in applying scientific and technical know- ledge to U.S. public policy issues. The Fellow must be able to work quickly and communicate effectively on a wide variety of topics, and be able to work cooperatively with individuals having diverse viewpoints. An applicant is expected to be a Member of OSA or MRS (or an applicant for membership) and have a doctorate.

\section{Award:} - The Fellow will have a oneyear appointment beginning September 1,2004. The Fellowship stipend will be $\$ 47,000$ to $\$ 50,000$, plus money for health insurance, travel and relocation expenses to the Washington, DC area. Final selection of the Fellow will be made in early 2004.

\section{Application:}

- Candidates should submit the following materials by January 15, 2004: (1) a detailed vita providing information about educational background, professional employment and activities, professional publications and presentations, public policy and legislative experience, and committee and advisory group appointments; (2) a statement of approximately 1000 words addressing the applicant's interests in the fellowship, career goals, contributions the applicant believes he or she can make as an MRS/OSA Fellow to the legislative process, and what the applicant wants to learn from the experience; and (3) three letters of reference, specifically addressing the applicant's ability to work on Capitol Hill as a special legislative assistant, sent directly to the address below.

\begin{tabular}{|l|}
\hline $\mathrm{M}$ \\
\hline $\mathrm{R}$ \\
\hline $\begin{array}{c}\text { MATERIALS } \\
\text { RESEARCH } \\
\text { SOCIETY }\end{array}$ \\
\hline
\end{tabular}

Application Material Should be Sent To

MRS/OSA Congressional Science and Engineering Fellow Program c/o Kimberly Mantuano

OSA, 2010 Massachusetts Avenue, NW, Washington, DC 20036-1023

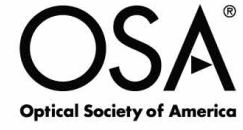

Optical Society of America

The deadline for applications is January 15, 2004.

For additional information, contact Kimberly Mantuano at (202) 416-1944 (kmantuano@osa.org) or Gail Oare at (724) 779-3004x501 (oare@mrs.org) 